\title{
CHROMOSOME NUMBERS FOR DALEA SPECIES (FABACEAE) FROM SOUTHWESTERN NEW MEXICO AND SOUTHEASTERN ARIZONA
}

\author{
Darrell E. Ward \& Richard Spellenberg
}

Box 30001, Biology Department, New Mexico State University, Las Cruces, New Mexico 88003-0001 U.S.A.

\section{$\&$}

\section{David Sutherland}

Biology Department, University of Nebraska at Omaha, Omaha, Nebraska 68182-0040 U.S.A.

\section{ABSTRACT}

Chromosome numbers are reported from New Mexico and Arizona for eleven taxa within the genus Dalea. These include counts for $D$. grayi and $D$. polygonoides, species previously counted only from Mexican material, and a new diploid count for $D$. albiflora.

KEY WORDS: Fabaceae, Dalea, chromosome number

The following chromosome number determinations were made from Dalea species growing in southwestern New Mexico and southeastern Arizona. Most of the counts are verifications of earlier counts, but a new diploid count is reported for Dalea albiflora, previously known only as a tetraploid. All collections were made on September 15, 16, and 17, 1989 by the three authors. The collection numbers are Sutherland's. Cytological material was stained in Snow's hydrochloric-acid-carmine stain (Snow 1963). Voucher specimens are deposited at NMC with some duplicates at OMA and NY.

Dalea albiflora A. Gray. $n=7$. UNITED STATES. Arizona: Cochise Co., 1.6 km NW of Bisbee along Old Hwy 80 (old road to Mule Pass), \#6874. $n=14$. New Mexico: Sierra Co., E of the Mimbres Mts., $22.5 \mathrm{~km} \mathrm{~N}$ of 
Nutt, $0.8 \mathrm{~km} \mathrm{~N}$ of Lakewood, \#6851; Arizona: Cochise Co., Geronimo Trail Road, $5.5 \mathrm{~km} \mathrm{~W}$ of the summit, \#6882. The diploid count was from a vigorous plant, with numerous stems arising from a woody, branched caudex. The two tetraploid counts reported here and the ones previously reported (Ward \& Spellenberg 1988, as D. ordiae A. Gray) are all from slender plants that have stems arising singly and in small clusters from along a slender, creeping rootstock. This complex and variable taxon is in need of further study.

Dalea brachystachys A. Gray. $n=7$. UNITED STATES. New Mexico: Sierra Co., $\mathrm{E}$ of the Mimbres Mts., along NM Hwy 27, $3.4 \mathrm{~km} \mathrm{~S}$ of Hillsboro, \#6852; $\mathrm{E}$ of the Mimbres Mts., along NM Hwy 152 by bridge over Percha Creek, $11.7 \mathrm{~km} \mathrm{~W}$ of Hillsboro, $2.2 \mathrm{~km} \mathrm{E}$ of Kingston, \#6859. These agree with previous counts from Texas (Turner \& Fearing 1960) and from México (Mosquin 1977).

Dalea filiformis A. Gray. $n=7$. UNITED STATES. New Mexico: Grant Co., $5.5 \mathrm{~km}$ east of Hanover, $12.9 \mathrm{~km}$ east of Central, along NM Hwy 152, \#6861. This is in agreement with previous counts from Arizona (Ward \& Spellenberg 1988) and from México (Mosquin 1977).

Dalea grayi (Vail) L.O. Williams. $n=7$. UNITED STATES. Arizona: Cochise Co., $22.5 \mathrm{~km}$ off U.S. Hwy 80 along road to Herb Martyr, \#6868; Arizona: Cochise Co., $1.6 \mathrm{~km} \mathrm{NW}$ of Bisbee along Old Hwy 80 (old road to Mule Pass), \#6875; Arizona: Cochise Co., W slope of Peloncillo Mts., Geronimo Trail Rd., $5.5 \mathrm{~km} \mathrm{~W}$ of the summit, \#6883. These agree with a previous count from México (Mosquin 1977).

Dalea lachnostachys A. Gray. $n=7$. UNITED STATES. New Mexico: Sierra Co., E of the Mimbres Mts., along NM Hwy 27, $3.4 \mathrm{~km} \mathrm{~S}$ of Hillsboro, \#6853; Arizona: Cochise Co., Geronimo Trail Rd., $4.3 \mathrm{~km}$ E of Douglas. \# 6876. These agree with previous counts from Texas (Turner \& Fearing 1960) and from México (Mosquin 1977; Spellenberg 1979).

Dalea leporina (Aiton) Bullock. $n=7$. UNITED STATES. New Mexico: Sierra Co., E of the Mimbres Mts., along NM Hwy 27, $3 \mathrm{~km} \mathrm{~S}$ of Hillsboro, \#6856. This agrees with previous counts for this species from eastern North America, México, and undisclosed locations (Atchison 1949, as D. alopecuroides Willd.; Spellenberg 1973; Mosquin 1977).

Dalea nana Torr. var. carnescens (Rydb.) Kearney \& Peebles. $n=7$. UNITED STATES. New Mexico: Sierra Co., E of the Mimbres Mts., $22.5 \mathrm{~km} \mathrm{~N}$ of Nutt, $0.8 \mathrm{~km} \mathrm{~N}$ of Lakewood, \#6850. This agrees with counts from Texas and México (Mosquin 1977). 
Dalea neomexicana (A. Gray) Cory var. neomexicana. $n=8$. UNITED STATES.

New Mexico: Sierra Co., E of the Mimbres Mts., along NM Hwy 27, 3.4 $\mathrm{km} \mathrm{S}$ of Hillsboro, \#6854. This is in agreement with previous counts from Texas (Spellenberg 1977) and from México (Mosquin 1977).

Dalea pogonathera A. Gray var. pogonathera. $n=7$. UNITED STATES. New Mexico: Sierra Co., E of the Mimbres Mts., along NM Hwy 27, 3.4 $\mathrm{km} \mathrm{S}$ of Hillsboro, \#6855. This agrees with a previous report from New Mexico (Spellenberg 1973) and with counts from Texas and México (Mosquin 1977).

Dalea polygonoides A. Gray. $n=7$. UNITED STATES. New Mexico: Sierra Co., E of the Mimbres Mts., along NM Hwy 152 by bridge over Percha Creek, $11.7 \mathrm{~km} \mathrm{~W}$ of Hillsboro, $2.2 \mathrm{~km} \mathrm{E}$ of Kingston, \#6858; New Mexico: Grant Co., $5.5 \mathrm{~km}$ east of Hanover, $12.9 \mathrm{~km}$ east of Central, along NM Hwy 152, \#6862. These counts agree with a report from México (Mosquin 1977).

Dalea versicolor Zucc. var. sessilis (A. Gray) Barneby. $n=7$. UNITED STATES. Arizona: Cochise Co., Geronimo Trail Road, $4.7 \mathrm{~km}$ W of the summit, \#6882. This agrees with previous counts reported by Spellenberg (1973) from México and Arizona.

\section{LITERATURE CITED}

Atchison, E. 1949. Studies in the Leguminosae IV. Chromosome numbers and geographical relationships of miscellaneous Leguminosae. Jour. Elisha Mitchell Sci. Soc. 65:118.

Mosquin, T. 1977. In: R. Barneby. Daleae Imagines. Mem. N.Y. Bot. Gard. 27:588-589.

Snow, R. 1963. Alcoholic hydrochloric acid-carmine as a stain for chromosomes in squash preparations. Stain Technol. 38:9-13.

Spellenberg, R. 1973. In A. Löve. IOBP Chromosome number reports. Taxon 22:653-654.

Spellenberg, R. 1977. In: R. Barneby. Daleae Imagines. Mem. N.Y. Bot. Gard. 27:589.

Spellenberg, R. 1979. Chromosome numbers from some federally proposed threatened or endangered southwestern angiosperms and other miscellaneous taxa. Southw. Naturalist 24:187-206. 
Turner, B.L. \& O.S. Fearing. 1960. Chromosome numbers in the Leguminosae. III. Species of the southwestern United States and Mexico. Amer. Jour. Bot. 47:603-608.

Ward, D.E. \& R. Spellenberg. 1988. Chromosome counts of angiosperms from New Mexico and adjacent areas. Phytologia 64:390-398. 


\section{$2 \mathrm{BHL}$ Biodiversity Heritage Library}

Spellenberg, Richard, Sutherland, D, and Ward, Darrell E. 1993. "Chromosome numbers for Dalea species (Fabaceae) from southwestern New Mexico and southeastern Arizona." Phytologia 75, 166-169.

https://doi.org/10.5962/bhl.part.17308.

View This Item Online: https://www.biodiversitylibrary.org/item/47083

DOI: https://doi.org/10.5962/bhl.part.17308

Permalink: https://www.biodiversitylibrary.org/partpdf/17308

\section{Holding Institution}

New York Botanical Garden, LuEsther T. Mertz Library

\section{Sponsored by}

The LuEsther T Mertz Library, the New York Botanical Garden

\section{Copyright \& Reuse}

Copyright Status: In copyright. Digitized with the permission of the rights holder.

Rights Holder: Phytologia

License: http://creativecommons.org/licenses/by-nc-sa/3.0/

Rights: https://biodiversitylibrary.org/permissions

This document was created from content at the Biodiversity Heritage Library, the world's largest open access digital library for biodiversity literature and archives. Visit BHL at https://www.biodiversitylibrary.org. 